\title{
ON THE INFLUENCES OF LOADING CASES AND INERTIAL CHARACTERISTICS ON THE BEHAVIOUR OF A FLOATING CRANE
}

\author{
Paul A. Pascu \\ NASDIS Consulting SRL, \\ 6, Tecuci Street, B1.V5, Et. 1, Galați, \\ 800120, România, \\ E-mail: paul.pascu@nasdis.ro
}

\author{
Liviu Crudu \\ "Dunărea de Jos" University of Galaţi, \\ Faculty of Naval Architecture, \\ 47, Domnească Street, 800008, România, \\ E-mail: liviu.crudu@ugal.ro
}

\begin{abstract}
The evaluation of the dynamics of floating structures has to be investigated in order to define the operational index which is reflecting the ability to operate at certain sea state. The applications have been performed for a floating crane using a range of operational loading cases and sea states in the Black Sea coastal area. The influence of the way to evaluate the moments of inertia for the different loading cases is also systematically taken into account. The conclusions are formulated based on the comparative diagrams, incorporating the influences of the above mentioned parameters.
\end{abstract}

Keywords: Dynamics of floating structures, Seakeeping, Operational Index, Accelerations, Floating cranes.

\section{INTRODUCTION}

The ability to operate at relatively high sea states is practically defining the quality of the design of floating structures which a conceived to perform different operations at zero speed [8]. Among the parameters which have to be accurately considered are the mass distributions for all loading cases, the hydrodynamic "transparency" from the geometrical point of view, the characteristics of the location where the floating structure will operate, the wave theory to be used, etc.

The applications have been carried out for a floating crane operating in the coastal area of the Black Sea area. The sea spectrum was defined for the location called "Lebăda".
The systematic measurements have been performed by INMH Bucharest and the spectrum definition was developed in cooperation with ICEPRONAV Galati in 1988 [2], [3].

The main characteristics of the body are: $\mathrm{L}_{\mathrm{pp}}=64.2 \mathrm{~m}, \mathrm{~B}=24 \mathrm{~m}, \mathrm{~T}=3.1 \mathrm{~m}, \mathrm{C}_{\mathrm{B}}=0.86$ and a displacement of $\Delta=4166 \mathrm{t}$. The body plan of the floating crane is presented in Figure 1 and a 3-D view in Figure 2.
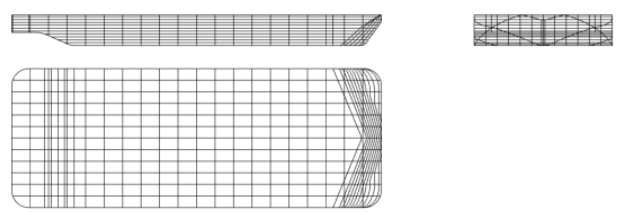

Fig. 1. The body plan of the floating crane 
In order to evaluate the influence of the loading cases (LC) on the general behaviour of the floating body, 4 significant ones have been analysed. An example is presented in Fig. 3.
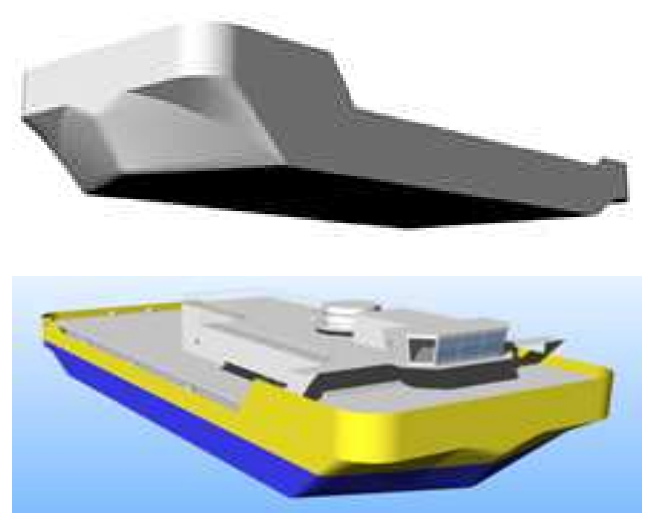

Fig. 2. The 3D views of the floating crane

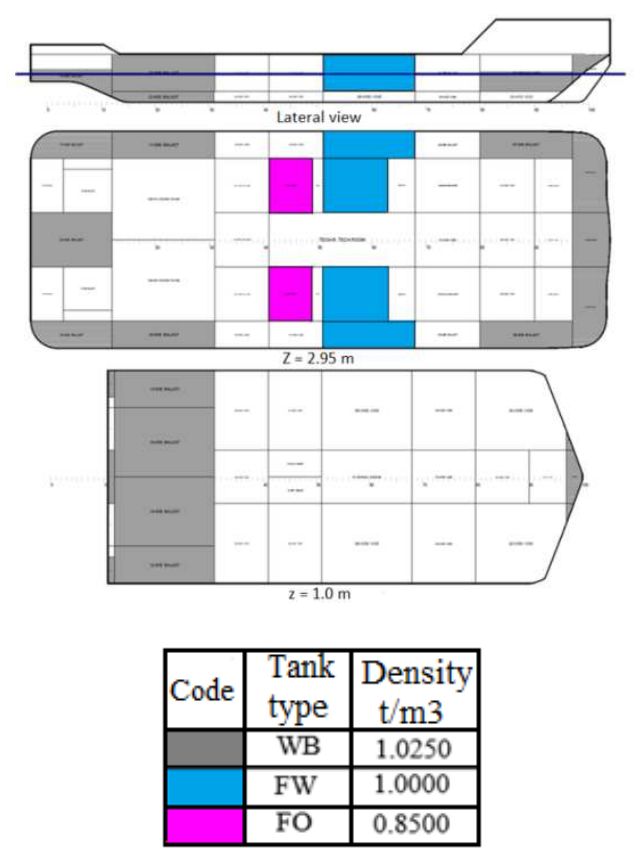

Fig. 3. Typical description of a loading case (LC1 - 98\% Bunker and WB)

The detailed characteristics of the loading cases are presented in Table 1. The displacements, the positions of the centre of gravity and the vertical coordinate of the centre of the buoyancy are presented for each loading cases.

Table 1. Main characteristics of the loading

\begin{tabular}{|c|c|c|c|c|}
\hline Items & $\begin{array}{c}98 \% \\
\text { Bunker } \\
\text { and WB }\end{array}$ & $\begin{array}{c}10 \% \\
\text { Bunker } \\
\text { and WB }\end{array}$ & $\begin{array}{c}98 \% \\
\text { Bunker } \\
\text { and } \\
\text { WB }+72\end{array}$ & $\begin{array}{c}10 \% \\
\text { Bunker } \\
\text { and } \\
\text { WB }+72\end{array}$ \\
\hline $\begin{array}{c}\text { Deadweight } \\
{[\mathrm{t}]}\end{array}$ & 2190.9 & 2145.3 & 2262.9 & 2217.3 \\
\hline Lightship [t] & 2000.0 & 2000.0 & 2000.0 & 2000.0 \\
\hline $\begin{array}{c}\text { Displacement } \\
{[\mathrm{t}]}\end{array}$ & 4190.9 & 4145.3 & 4262.9 & 4217.3 \\
\hline $\mathrm{X}_{\mathrm{G}}[\mathrm{m}]$ & 31.9 & 31.151 & 30.650 & 30.704 \\
\hline $\mathrm{Y}_{\mathrm{G}}[\mathrm{m}]$ & 0.0 & -0.007 & 0.136 & 0.130 \\
\hline $\mathrm{Z}_{\mathrm{G}}[\mathrm{m}]$ & 5.745 & 5.779 & 5.834 & 5.868 \\
\hline $\mathrm{Z}_{\mathrm{B}}[\mathrm{m}]$ & 1.620 & 1.605 & 1.648 & 1.632 \\
\hline Draft $[\mathrm{m}]$ & 3.112 & 3.085 & 3.157 & 3.127 \\
\hline BMt $[\mathrm{m}]$ & 16.988 & 17.152 & 16.678 & 16.853 \\
\hline
\end{tabular}

As compared to the ship case, when simple formulas can be used for the evaluation of the moments of inertia, for floating structures these approximations could lead to significant errors.

Table 2. Radii of inertia for each loading case

\begin{tabular}{|c|c|c|c|c|}
\hline $\begin{array}{c}\text { Displacement } \\
\text { and radii of } \\
\text { inertia }\end{array}$ & $\begin{array}{c}98 \% \\
\text { Bunker } \\
\text { and WB } \\
\text { (LC1) }\end{array}$ & $\begin{array}{c}10 \% \\
\text { Bunker } \\
\text { and WB } \\
\text { (LC2) }\end{array}$ & $\begin{array}{c}98 \% \\
\text { Bunker } \\
\text { and } \\
\text { WB+72 } \\
\text { (LC3) }\end{array}$ & $\begin{array}{c}10 \% \\
\text { Bunker } \\
\text { and } \\
\text { WB }+72 t \\
\text { (LC4) }\end{array}$ \\
\hline $\begin{array}{c}\text { Displacement } \\
\text { [t] }\end{array}$ & 4190.9 & 4145.3 & 4262.9 & 4217.3 \\
\hline $\mathrm{r}_{\mathrm{zx}}[\mathrm{m}]$ & 8.185 & 8.143 & 8.410 & 8.192 \\
\hline $\mathrm{r}_{\mathrm{yy}}[\mathrm{m}]$ & 25.866 & 22.234 & 25.616 & 22.387 \\
\hline $\mathrm{r}_{\mathrm{zz}}[\mathrm{m}]$ & 26.276 & 22.750 & 25.987 & 22.908 \\
\hline
\end{tabular}

\section{INFLUENCE OF INERTIAL CHARACTERISTICS ON THE FLOATING CRAINE MOTIONS}

The evaluation of influences of inertial characteristics on the Response Amplitude Operators has been performed for loading case LC1. When ship case is considered, different simple formulas are used. For roll radius of gyration a coefficient between 0.26 $\div 0.30 \mathrm{~B}$, where $\mathrm{B}$ is ship breadth, can be 
used and this is based on quite large statistic evidence. Similarly, simple evaluations can be used for pitch and yaw radii of gyrations when a coefficient of about $0.25 \mathrm{~L}$ (ship length) is commonly used. It can be observed that using such formulas there are no differences between the different loading cases. Constant values of about $7.20 \mathrm{~m}$ for roll radius of gyration and $20.0 \mathrm{~m}$ for pitch and yaw ones are enough far from the values presented in Table 2 and the influences have to be taken into account.

Consequently, due to totally unusual mass distributions, when offshore floating structures or even offshore ship shaped structures are considered, weights distributions are mandatory for accurate calculations.

The influences are presented in the following figures.

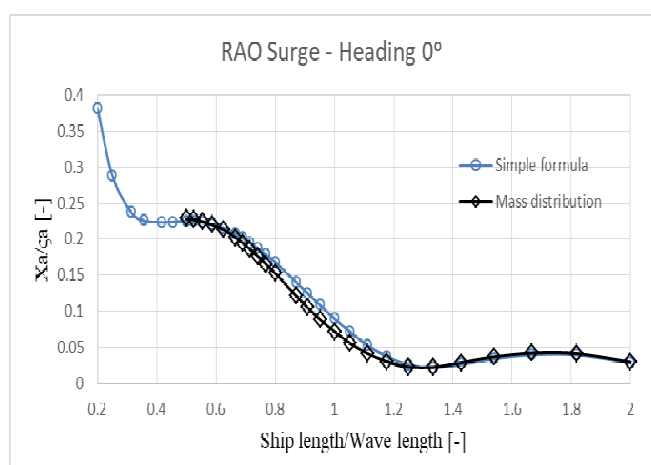

Fig. 4. RAO surge -comparative results (Heading $0^{0}$ )

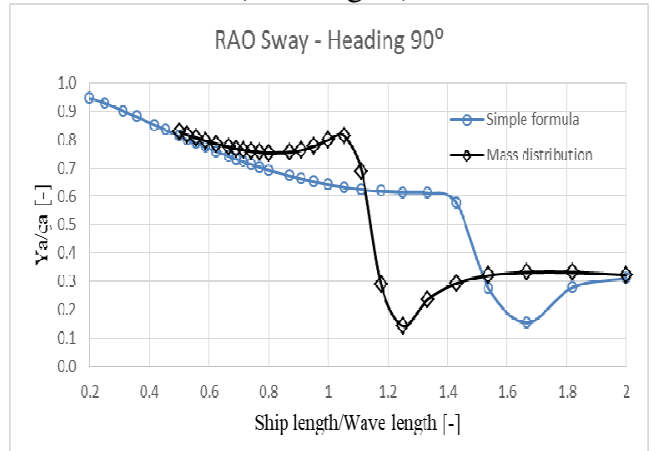

Fig. 5. RAO sway -comparative results (Heading 90 $)$

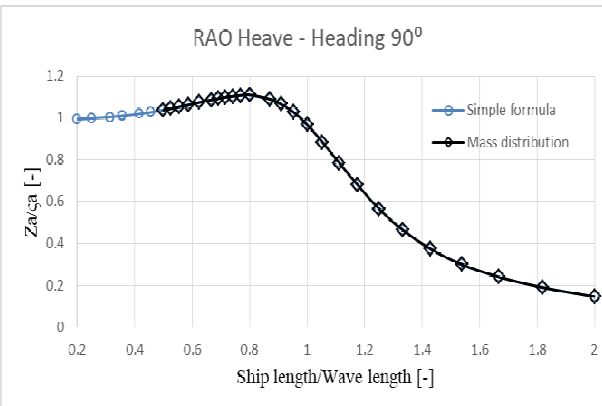

Fig. 6. RAO heave -comparative results (Heading 90 $)$

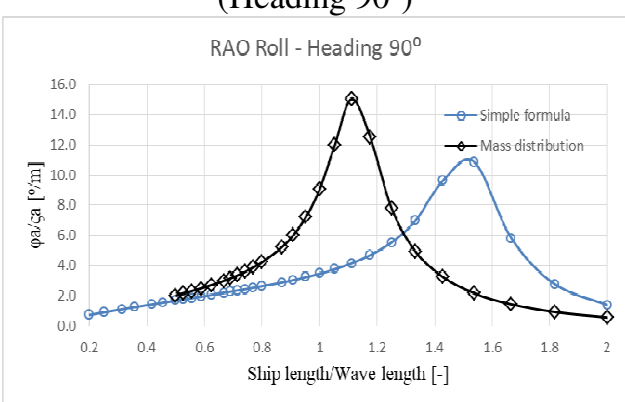

Fig. 7. RAO roll -comparative results (Heading 90 $)$

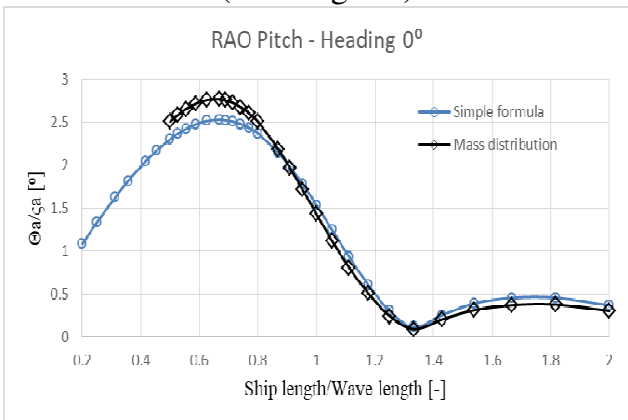

Fig. 8. RAO pitch -comparative results (Heading $0^{0}$ )

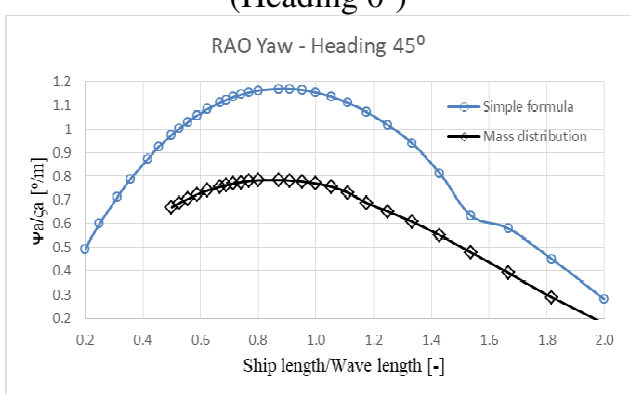

Fig. 9. RAO yaw -comparative results (Heading $45^{\circ}$ ) 


\section{INFLUENCES OF LOADING CASES ON THE FLOATING CRAINE MOTIONS}

The Response Amplitude Operators (RAO's) have been calculated for the above mentioned loading cases (LC) using the mass distributions as well as using the simple formulas for the moments of inertia. The results are presented in the following figures.

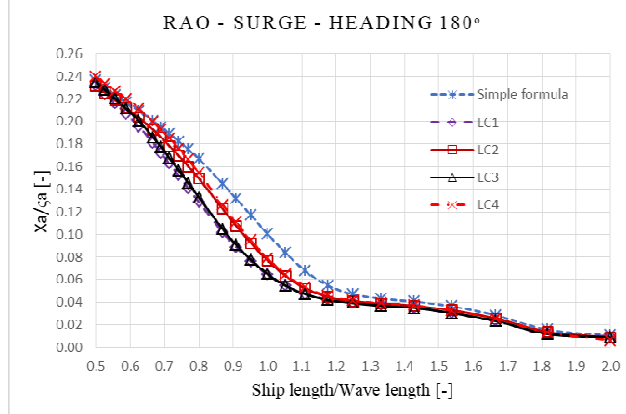

Fig. 10. RAO surge as a function of the loading cases, heading $180^{\circ}$

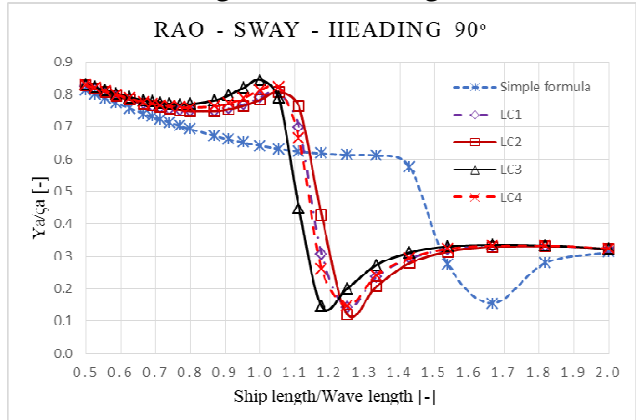

Fig. 11. RAO sway as a function of the loading cases, heading $90^{\circ}$ RAO - HFAVF - HF.ADING 90"

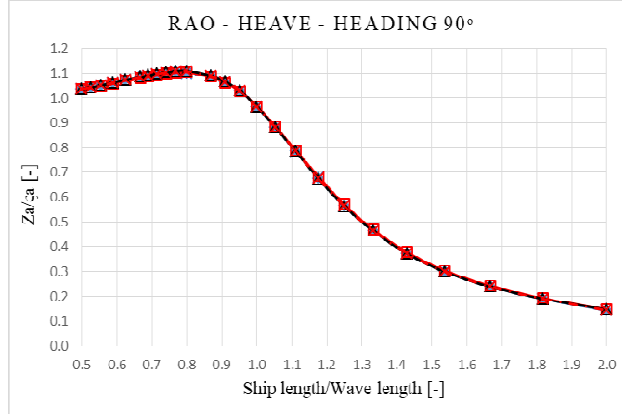

Fig. 12. RAO heave as a function of the loading cases, heading $90^{\circ}$

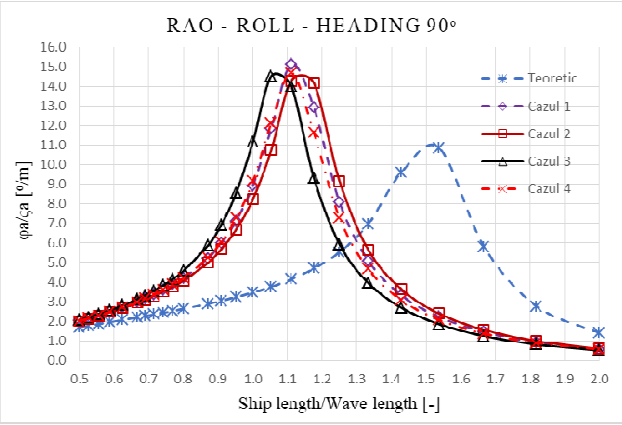

Fig. 13. RAO roll as a function of the loading cases, heading $90^{\circ}$

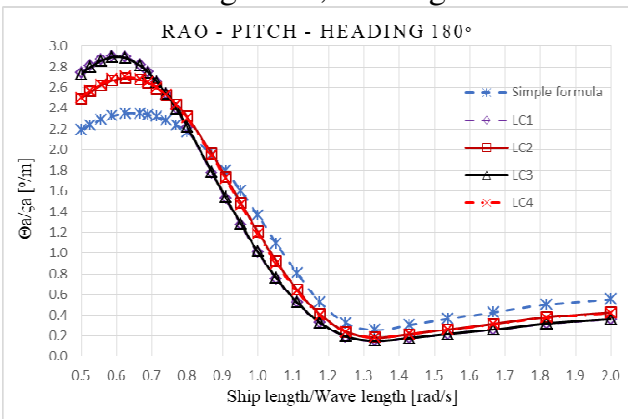

Fig. 14. RAO pitch as a function of the loading cases, heading $180^{\circ}$

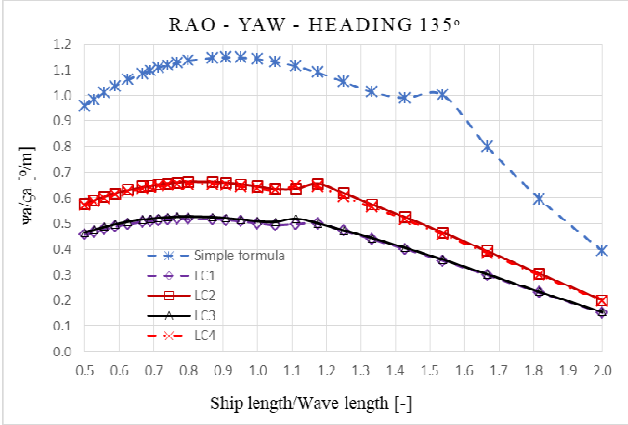

Fig. 15. RAO yaw as a function of the loading cases, heading $180^{\circ}$

The calculations have been performed for a range of heading angles between $0^{\circ} \div 180^{\circ}$ with a step of $15^{\circ}$.

\section{DEFINITION OF BLACK SEA SPECTRA FOR APPLICATIONS}

The evaluations were made for a range of sea states defined based on wind speed in the coastal area of Black Sea, location 
"Lebada". Four different wind speeds have been, from $10 \mathrm{~m} / \mathrm{s}$ to $25 \mathrm{~m} / \mathrm{s}$ with a step of 5 $\mathrm{m} / \mathrm{s}$. The results are graphically presented in Figure 14.

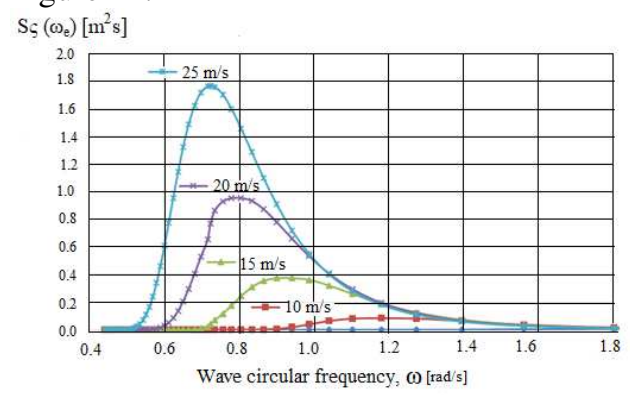

Fig. 16. The sea spectra used for applications The main characteristics of the sea states are presented in Table 3.

Table 3. Wave characteristics of the sea states

\begin{tabular}{|l|r|r|r|r|}
\cline { 2 - 5 } \multicolumn{1}{c|}{} & $v=10 \mathrm{~m} / \mathrm{s}$ & $v=15 \mathrm{~m} / \mathrm{s}$ & $v=20 \mathrm{~m} / \mathrm{s}$ & $v=25 \mathrm{~m} / \mathrm{s}$ \\
\hline HMAXPROB $=$ & 1.551 & 2.812 & 4.079 & 5.206 \\
\hline HMAXP $=$ & 2.048 & 3.747 & 5.468 & 7.009 \\
\hline HMED $=$ & 0.494 & 0.887 & 1.285 & 1.643 \\
\hline H1/3= & 0.788 & 1.415 & 2.052 & 2.623 \\
\hline H1 $/ 10=$ & 1.003 & 1.801 & 2.611 & 3.338 \\
\hline H1 $100=$ & 1.315 & 2.360 & 3.422 & 4.374 \\
\hline PERMEDTZ $=$ & 4.336 & 5.555 & 6.500 & 7.245 \\
\hline T1/3= & 5.283 & 5.993 & 6.487 & 6.851 \\
\hline
\end{tabular}

The notations used refer to the wave characteristics consisting in probabilistic values like significant heights, significant $1 / 3$ period in seconds and wave heights for a certain level of probability. The symbol SS1 to SS4 represents the sea state.

\section{EVALUATION OF MOTIONS AND OPERATIONAL LIMITS}

Based on RAO's calculations, as a next step the response spectra of motions and accelerations have been evaluated using the well-known expression [1]

$$
S_{x}\left(\omega_{e}\right)=R A O^{2}\left(\omega_{e}\right) \cdot S_{\zeta}\left(\omega_{e}\right)
$$

where, $S_{x}(\omega)$ represents the generic response spectra which allow the determination of statistic values to be compared with the recommended ones [4], presented in Table 4.

Table 4. Recommended limits for different types of activities

\begin{tabular}{|c|c|c|c|}
\hline \multicolumn{3}{|c|}{ RMS criteria } & \multirow[b]{2}{*}{$\begin{array}{l}\text { Type of } \\
\text { activity }\end{array}$} \\
\hline $\begin{array}{c}\text { Vertical } \\
\text { acceleration } \\
\left(\mathrm{a}_{\mathrm{z}}\right)\end{array}$ & $\begin{array}{c}\text { Lateral } \\
\text { acceleration } \\
\left(a_{\mathrm{y}}\right)\end{array}$ & $\begin{array}{c}\text { Roll } \\
\text { motion } \\
(\varphi)\end{array}$ & \\
\hline $0.20 \mathrm{~g}$ & $0.10 \mathrm{~g}$ & $6.0^{\circ}$ & $\begin{array}{c}\text { Light } \\
\text { manual } \\
\text { work }\end{array}$ \\
\hline $0.15 \mathrm{~g}$ & $0.07 \mathrm{~g}$ & $4.0^{\circ}$ & $\begin{array}{c}\text { Heavy } \\
\text { manual } \\
\text { work }\end{array}$ \\
\hline $0.10 \mathrm{~g}$ & $0.05 \mathrm{~g}$ & $3.0^{\circ}$ & $\begin{array}{c}\text { Intellectual } \\
\text { work }\end{array}$ \\
\hline
\end{tabular}

The calculations have been performed for all loading cases, the already mentioned range of wave frequencies and for two distinct situations: Beam Sea and Head Sea [6].

\section{a) The beam sea case}

For beam sea the measuring point is marked in Fig. 15.

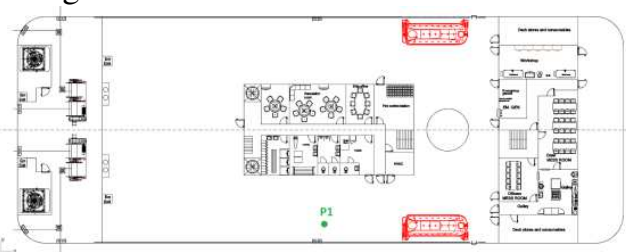

Fig. 17. The measuring point for the beam sea case

The results are presented in the following tables for the lateral accelerations $\left(a_{y}\right)$, vertical accelerations $\left(a_{z}\right)$ and roll motions. It is important to underline that the values of the accelerations are practically parts of the gravitational acceleration.

Table 5. The results for the lateral accelerations

\begin{tabular}{|c|c|c|c|c|}
\hline SS1 & SS2 & SS3 & SS4 & $\mathbf{a}_{\mathbf{y}}$ \\
\hline 0.017 & 0.041 & 0.058 & 0.065 & $\mathrm{ay}_{1 / 3}$ \\
\hline 0.022 & 0.052 & 0.074 & 0.083 & $\mathrm{ay}_{1 / 10}$ \\
\hline 0.029 & 0.069 & 0.096 & 0.109 & $\mathrm{ay}_{1 / 100}$ \\
\hline $\mathbf{0 . 0 0 9}$ & $\mathbf{0 . 0 2 2}$ & $\mathbf{0 . 0 3}$ & $\mathbf{0 . 0 3 4}$ & $\mathbf{R M S}$ \\
\hline
\end{tabular}


Table 6. The results for the vertical accelerations

\begin{tabular}{|c|c|c|c|c|}
\hline SS1 & SS2 & SS3 & SS4 & $\mathbf{a}_{\mathbf{z}}$ \\
\hline 0.07 & 0.161 & 0.197 & 0.205 & $\mathrm{az}_{1 / 3}$ \\
\hline 0.89 & 0.204 & 0.25 & 0.261 & $\mathrm{az}_{1 / 10}$ \\
\hline 0.117 & 0.268 & 0.328 & 0.342 & $\mathrm{az}_{1 / 100}$ \\
\hline $\mathbf{0 . 3 6}$ & $\mathbf{0 . 0 8 2}$ & $\mathbf{0 . 1}$ & $\mathbf{0 . 1 0 5}$ & $\mathbf{R M S}$ \\
\hline
\end{tabular}

Table 7. The results for the roll motions

\begin{tabular}{|c|c|c|c|c|}
\hline SS1 & SS2 & SS3 & SS4 & $\varphi$ \\
\hline 0.806 & 1.89 & 2.442 & 2.65 & $\varphi_{1 / 3}$ \\
\hline 1.025 & 2.405 & 3.1 & 3.373 & $\varphi_{1 / 10}$ \\
\hline 1.343 & 3.152 & 4.072 & 4.42 & $\varphi_{/ 100}$ \\
\hline $\mathbf{0 . 4 0 8}$ & $\mathbf{0 . 9 6 5}$ & $\mathbf{1 . 2 6 1}$ & $\mathbf{1 . 3 7 8}$ & $\mathbf{R M S}$ \\
\hline
\end{tabular}

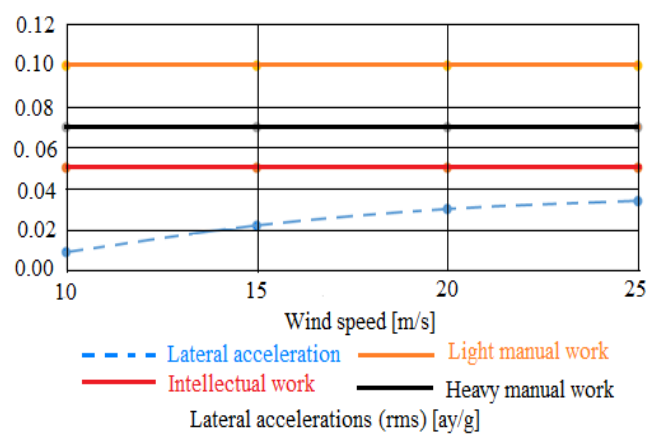

Fig. 18. Lateral accelerations according to Table 5

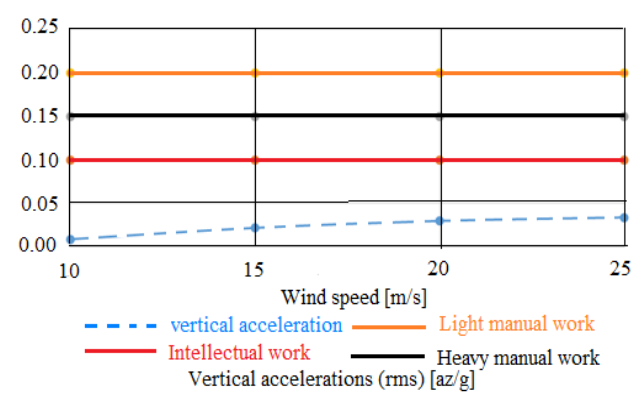

Fig. 19. Vertical accelerations according to Table 6

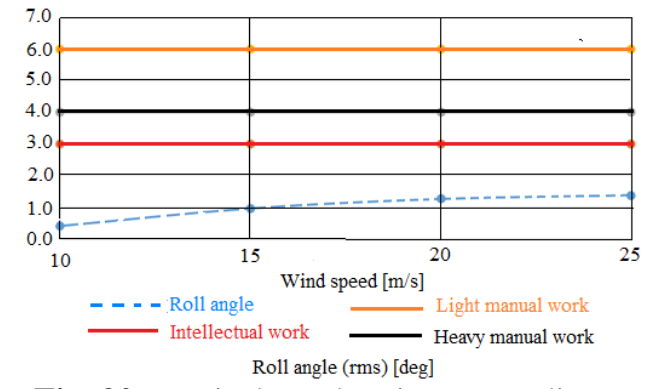

Fig. 20. Vertical accelerations according to Table 6

\section{b) The following sea case}

For the following sea case the measuring point is marked in Fig. 19.

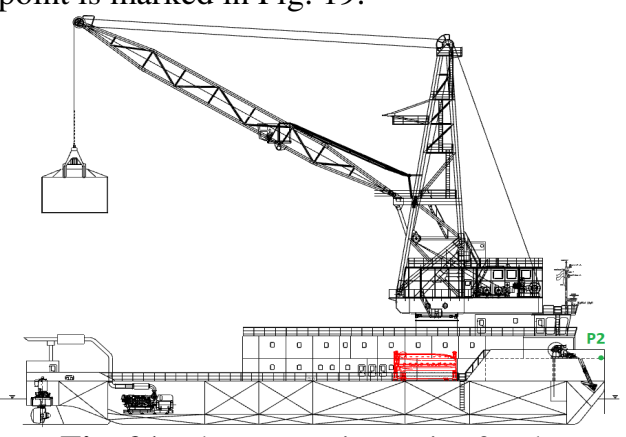

Fig. 21. The measuring point for the following sea case

The results are presented in the following tables in terms of vertical accelerations $\left(a_{x}\right)$, vertical accelerations $\left(a_{z}\right)$ and pitch motions.

Table 8. The results for the longitudinal accelerations

\begin{tabular}{|c|c|c|c|c|}
\hline SS1 & SS2 & SS3 & SS4 & $\mathbf{a}_{\mathbf{x}}$ \\
\hline 0.003 & 0.01 & 0.18 & 0.022 & $\mathrm{ax}_{1 / 3}$ \\
\hline 0.003 & 0.013 & 0.023 & 0.028 & $\mathrm{ax}_{1 / 10}$ \\
\hline 0.004 & 0.017 & 0.03 & 0.036 & $\mathrm{ax}_{1 / 100}$ \\
\hline $\mathbf{0 . 0 0 1}$ & $\mathbf{0 . 0 0 5}$ & $\mathbf{0 . 0 0 9}$ & $\mathbf{0 . 0 1 1}$ & $\mathbf{R M S}$ \\
\hline
\end{tabular}

Table 9. The results for the vertical accelerations

\begin{tabular}{|c|c|c|c|c|}
\hline SS1 & SS2 & SS3 & SS4 & $\mathbf{a}_{\mathbf{z}}$ \\
\hline 0.017 & 0.066 & 0.114 & 0.14 & $\mathrm{az}_{1 / 3}$ \\
\hline 0.022 & 0.084 & 0.145 & 0.178 & $\mathrm{az}_{1 / 10}$ \\
\hline 0.029 & 0.11 & 0.19 & 0.234 & $\mathrm{az}_{1 / 100}$ \\
\hline $\mathbf{0 . 0 2 2}$ & $\mathbf{0 . 0 3 4}$ & $\mathbf{0 . 0 5 6}$ & $\mathbf{0 . 0 7 2}$ & $\mathbf{R M S}$ \\
\hline
\end{tabular}


Table 10. The results for the pitch motions

\begin{tabular}{|c|c|c|c|c|}
\hline SS1 & SS2 & SS3 & SS4 & $\theta[\square]$ \\
\hline 0.23 & 0.858 & 1.49 & 1.848 & $\theta_{1 / 3}$ \\
\hline 0.293 & 1.092 & 1.897 & 2.351 & $\theta_{1 / 10}$ \\
\hline 0.384 & 1.431 & 2.486 & 3.082 & $\theta_{/ 100}$ \\
\hline $\mathbf{0 . 1 1 9}$ & $\mathbf{0 . 4 4 5}$ & $\mathbf{0 . 7 7}$ & $\mathbf{0 . 9 5 2}$ & $\mathbf{R M S}$ \\
\hline
\end{tabular}

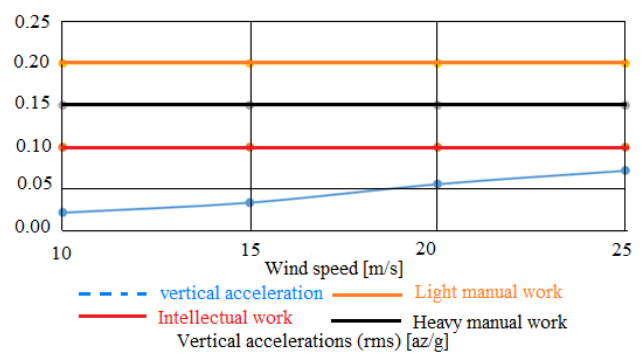

Fig. 22. Vertical accelerations according to Table 9

In both cases, i.e. beam and following sea respectively, the calculations have been performed for several points due to the necessity to evaluate the accelerations in sensitive areas where the dynamic effect has to be accurately known.

\section{CONCLUDING REMARKS}

The evaluation has been performed using a computer code based on the wellknown theory developed by Salvesen, Tuck and Faltinsen [5]. The program is able to calculate the amplitudes and phases for all six degrees of freedom, i.e. surge, sway, heave, roll, pitch and yaw motions as well as the hydrodynamic loads for any heading angle in regular waves. The slender body theory is assumed and the three dimensional hydrodynamic quantities are expressed in terms of the solution to the sectional twodimensional problem of a cylinder with the same shape as the individual cross-sections oscillating on the free surface. The program is using the "close fit source distribution technique" developed by Frank. The evaluation of the Response Amplitude
Operators (RAO's) of motions is performed in the frequency domain.

The first important conclusion is the linked to the necessity to use the mass distributions information in order to have enough accurate evaluation of the inertial characteristics of the body. The only motion which is not affected is heave as it can be observed in Fig. 6. Less affected are and pitch motions while sway, roll and yaw motions are dramatically influenced as depicted in Fig. 5, Fig. 7 and Fig. 9.

As regarding the influences of the loading cases, the evaluations do not show large differences. However, some significant discrepancies are mainly displayed when sway, roll and yaw motions are considered.

The evaluation of the accelerations and motions, carried out in order to observe the capability to operate from the comfort point of view, lead to the idea that there are no situations to be avoided. It has to be underlined that coastal area of the Black Sea has been considered, specifically the location Lebăda.

Mention should be made that, from the operational point of view, the "rms" values were used which means to estimate the expected motions and accelerations for short time operations limited in time to about 6 hours. If higher operational periods are required then, different approaches have to be considered [7]. To this purpose, just to give a rough idea, some other statistical values have been shown, for example $1 / 3$, $1 / 10$ and $1 / 100$.

\section{REFERENCES}

[1]. Bhattacharyya, R., "Dynamics of Marine Vehicles", John Wiley \& Sons Publishing House, New York, 1982;

[2]. Bâzâc, C., „Studiul regimului vânturilor în zona litoralului românesc al Mării Negre", Institutul Naţional de Meteorologie şi Hidrologie, Raport intern, Bucureşti, Decembrie 1988

[3]. Bondar, C., „Studiul regimului hidrologic al Mării Negre în Zona Lebăda", Institutul de 
Meteorologie şi Hidrologie, Raport intern, Bucureşti, Decembrie 1988

[4]. Nabergoj, R., "Passenger comfort and seakeeping: a new challenge for high-tech ship design", Proceedings of SMALL CRAFT, An International Conference on Small Craft Related Sciences \& Technology16 - 18 November 2006, Bodrum / Turkey;

[5]. Salvesen, N., Tuck, E.O., Faltisen, O., "Ship motions and Sea Loads", The Society of Naval Architects and Marine Engineers, Transactions, Volume 78, New York, 1970

[6]. Crudu L, Neculeț O., Mihalache C., "Influences of mass distribution on seakeeping performances of an offshore barge", The Annals of Dunarea de Jos University of Galati, Fascicle XI Shipbuilding 33 pp. 143-150, 2016

[7]. Faltinsen O. M., "Sea Loads on Ship and Offshore Structures" (Cambridge: Cambridge University Press), 1983

[8]. Crudu, L., 2015, "Theoretical and experimental applications in offshore engineering", University Foundation Press, „Dunarea de Jos” ISBN 978-973-627-548-7, $210 \mathrm{p}$.

Paper received on December $31^{\text {th }}$, 2018 